\title{
Anti-inflammatory and apoptosis improving effects of sulfasalazine and Cinnamomi cortex and Bupleuri radix mixture in TNBS-induced colitis mouse model
}

\author{
Kyeong Jo Kim ${ }^{1} \cdot$ Mi-Rae Shin ${ }^{1}$ Soo Hyun Kim ${ }^{1} \cdot$ Su Ji Kim ${ }^{1}$. \\ Ah Reum Lee ${ }^{1}$ O Jun Kwon ${ }^{2} \cdot$ Ki-Jung Kil ${ }^{3} \cdot$ Seong-Soo Roh $^{1}$
}

\section{TNBS로 유발된 마우스 대장염모델에서 설파살라진, 육계와 시호 복합 추출물의 항염중 및 세포 자멸 개선효과}

김경조 $^{1} \cdot$ 신미래 $^{1} \cdot$ 김수현 $^{1} \cdot$ 김수지 $^{1} \cdot$ 이아름 $^{1} \cdot$ 권오준 $^{2} \cdot$ 길기정 $^{3} \cdot$ 노성수 ${ }^{1}$

\begin{abstract}
Inflammatory bowel disease (IBD) is including Crohn's disease and ulcerative colitis. Sulfasalazine commonly used in IBD, possibly has various side effects after high dosage and long term intake. The present study aimed to investigate the sulfasalazine and combination with herbal medicine on 2,4,6trinitrobenzene sulfonic acid (TNBS)-induced in mice model. TNBS-induced mice were injected through a flexible catheter $4 \mathrm{~cm}$ in length $1.6 \mathrm{mg}$ TNBS. Animals were divided into five groups $(n=12)$ : Normal group, TNBS control group, Sulfasalazine $(30 \mathrm{mg} / \mathrm{kg})$ group, Sulfasalazine $(60 \mathrm{mg} / \mathrm{kg})$ group, Sulfasalazine $(30 \mathrm{mg} / \mathrm{kg})+$ Cinnamomi cortex and Bupleuri radix mixture $(30$ $\mathrm{mg} / \mathrm{kg}$ ) (SCB) group. Administration groups were fed extract
\end{abstract}

Seong-Soo Roh $(\triangle)$

E-mail: ddede@dhu.ac.kr

${ }^{1}$ College of Korean Medicine, Daegu Haany University, 136, Shinchendongro, Suseong-gu, Deagu 42158, Republic of Korea

${ }^{2}$ Gyeongbuk Regional industry Evaluation, Daegyeong Institute for Regional Program Evalution, 27, Sampung-ro, Gyeongsan-si, Gyeongsangbuk-do, 38542 Republic of Korea

${ }^{3}$ Department of Herbal pharmaceutical Science, Joongbu University, Daehak-ro, Chubu-myeon, Geumsan-gun, Chungcheongnam-do, 32713, Republic of Korea

This is an Open Access article distributed under the terms of the Creative Commons Attribution Non-Commercial License (http://creativecommons. org/licenses/by-nc/3.0/) which permits unrestricted non-commercial use, distribution, and reproduction in any medium, provided the original work is properly cited. during 7 days. The inflammatory, and apoptotic protein levels were determined using western blotting. SCB treatment showed an outstanding effectiveness in counteracting the IBD, as assessed by reduction of body weight loss, down-regulation of proinflammatory proteins and cytokines, and by inhibition of proteins related to apoptosis. This is the first report that sulfasalazine and Cinnamomi cortex plus Bupleuri radix mixture improve the severity of experimental IBD through the inhibition of both inflammation and apoptosis. We confirm that the SCB treatment instead of sulfasalazine alone may be promising as an alternative therapeutic plan against IBD, without any evidence of adverse effects.

Keywords Anti-inflammatory · Apoptosis · Bupleuri radix · Cinnamomi cortex · Inflammatory bowel disease ·

Trinitrobenzene sulfonic acid

\section{서 론}

염증성 장질환(Inflammatory bowel disease; IBD)은 과거 서양 에서만 주로 발생하는 질환으로 우리나라에서는 매우 드문 질 병으로 알려져 왔으나, 최근 우리나라의 식생활이 서구화되면서, 그 환자 수가 급증하고 있다 $(\mathrm{Kim}$ 등, 2008a; Kim 등, 2013). 감염성 기원이라고 추정되는 설사 및 위장염, 크론병, 궤양성 대장염, 기타 장관 감염성 질환으로 병원치료를 받은 횟수가 
2004년 3,129,707회에서 2012년 5,218,879회로 급증하고 있다 (Kim 등, 2015). IBD는 임상에서는 복통, 설사, 농혈, 점액변이 주요한 증상이며, 병변은 점막 및 점막하층에서 주로 나타나고 병리학적으로 볼 때 궤양이 형성되고 각종의 염증 세포가 생성 되는 등의 비특이성 증상이 있다(Cho와 $\mathrm{Kim} 2009) . \mathrm{IBD}$ 는 임 상적 양상, 형태학적 양상에 따라 궤양성 대장염(Ulcerative colitis)과 크론씨 병(Crohn's disease)으로 구분하고 있다. 그러나 이들에 대한 정확한 발병원인은 아직까지 밝혀지지 않고 있어 대장염 치료에 대한 정확한 접근이 어려울 뿐만 아니라 그로 인해 약물치료에 의한 완치 또한 어렵다(Myung 2014; Hyun과 Hur 2011). 현재 임상에서는 대장염의 염증 및 면역 반응을 전 반적으로 억제하는 치료법으로 sulfasalazine과 스테로이드제 등 을 이용한 약물치료법을 사용하고 있으나 sulfasalazine은 간, 신 장독성이 있어 근본적인 치료는 이루어지지 못하고 있으며 장 기간 사용에 의한 부작용과 재발가능성 및 대장암으로 발전할 가능성이 있기에 sulfasalazine 사용의 문제점으로 대두되고 있 다(Kye 2016). 최근 대장염 치료에 있어서 부작용과 독성 그리 고 내성이 적고 안전한 진통제 및 항염증제의 개발이 요구되고 있고 천연물은 이러한 소재의 중요한 원천으로 여겨지고 있다 (Lee와 Rhee 2010; Je 2012; Kim 등, 2015).

육계는 녹나무과(Lauraceae)에 속한 상록교목인 육계 Cinnamomum cassia Presl. 의 나무 줄기 껍질을 건조한 것이다 (Park과 Seo 2015). 육계는 해열 및 소염 - 진통 작용이 있고, 말초혈관의 이완작용으로 혈압을 저하시키는 작용이 있으며, 면 역 및 항암작용, 항균작용 등이 있음이 알려져 있다(Kim과 Yoo 2012). 최근 연구결과에 따르면 항미생물 및 항암효과까지 나타 내는 것으로 밝혀졌으며, Lee 등(2006)의 연구에서는 육계 추 출물이 대장암 세포의 성장을 감소시킨다고 하였다.

시호는 미나리과(Umverllifeae)에 속하는 식물로 시호 Bupleurum falcatum L.의 뿌리를 건조하여 약용부위로 사용하고 있다. 폐 질환, 간질환 등의 예방과 치료에 필수적인 약재 중의 하나로 이용되고 있으며, 만성간염 및 바이러스성 간염과 같은 간질환 을 치료하기 위해 사용되어 왔다(Cho와 Kim 1994; Wong 등, 2005; Cho와 Kim 2009). 따라서 대장염을 치료하는데 있어 항 염효과가 뛰어난 육계와 간 및 신장 보호 효과가 뛰어난 시호 복합물이 상승 효과를 발휘할 것으로 예상하여 연구를 진행하 게 되었다.

본 연구에서는 Sulfasalazine의 독성 및 부작용을 최소화 하 면서 효과를 높일 수 있는 치료제로 Sulfasalazine 육계 시호 복 합 추출물 $(\mathrm{SCB})$ 의 가능성을 검토하고자 $\mathrm{TNBS}$ 로 유발한 마우 스 대장염 모델에서 한양방 복합물의 유의한 치료효과를 얻었 기에 이를 보고하고자 하는 바이다.

\section{재료 및 방법}

\section{실험 재료}

실험에 사용된 육계(Cinnamomi Cortex)는 전라북도 전주시 약 재시장에서 구입하여 시료제조에 사용하였고, 시호(Bupleuri radix)는 본초원(영천시, 경상남도, 대한민국)에서 공급받아 사용 하였다.
시약

TNBS Solution (2,4,6-trinitrobenzene sulfonic acid 5\% w/v)과 단백질 정량을 위한 BCA protein assay kit는 Thermo Scientific (Rockford, IL, USA)에서 구입하였고, sulfasalazine (purity $\geq 98 \%$ ), phenylmethylsulfonyl fluoride (PMSF)는 Sigma-Aldrich (St, Louis, MO, USA)에서 구입하였다. Nitrocellulose membranes 는 Amersham GE Healthcare (Little. Chalfont, UK)에서 구입 하였으며, tumor necrosis factor alpha (TNF- $\alpha)$, interleukin-6 (IL-6), interleukin-1 $\beta$ (IL-1 $\beta$ ), monocyte chemoattractant peptide1 (MCP-1), bax, cytochrome C, cysteine aspartyl-specific proteases-3 (caspase-3), $\beta$-actin과 2차 항체인 rabbit anti-goat, goat anti-rabbit, goat anti-mouse는 Santa Cruz Biotechnology (Santa Cruz, Dallas, CA, USA)로부터 구입하였으며, dimethylsulfoxide, ethylenediaminetetraacetic acid (EDTA)는 Wako Pure Chemical Industries, Ltd. (Osaka. Japan)에서 구입 하였다. 또한, 2',7'-Dichlorofluorescein diacetate (DCFH-DA)와 dihydrorhodamine 123은 Molecular Probes (Eugene, OR, USA) 에서 ECL Western Blotting Detection Reagents는 GE Healthcare 로부터 구입하여 사용하였다.

\section{실험 동물}

생후 8주령의 체중 $25 \mathrm{~g}$ 내외의 수컷 $\mathrm{Balb} / \mathrm{C}$ mice (오리엔트, 경기도, 대한민국)를 구입하였으며, 동물 사육실의 조건은 conventional system으로 온도 $22 \pm 2{ }^{\circ} \mathrm{C}$, 습도 $50 \pm 5 \%$, 명암주기 (light-dark cycle)는 12시간 주기로 조절하였다. 사료는 고형사 료(조단백질 $22.1 \%$ 이상, 조지방 $8.0 \%$ 이하, 조섬유 $5.0 \%$ 이 하, 조회분 $8.0 \%$ 이하, 칼슘 $0.6 \%$ 이상, 인 $0.4 \%$ 이상, 삼양사, 항생제 무첨가)와 물을 충분히 공급하였다. 모든 실험은 대구한 의대학교 동물실험 윤리위원회의 승인(DHU2017-053)을 얻어 시행하였으며 동물관리 규정을 준수하였다.

\section{시료제조}

실험에 사용된 육계 시호 복합 추출물 중 시호 추출물을 얻기 위 하여 시호 $100 \mathrm{~g}$ 에 10 배수의 증류수를 가한 뒤 $100^{\circ} \mathrm{C}$ 에서 2 시간 동안 열수추출 하였다. 추출하여 얻은 액을 여과 후 감압추출장 치로 농축한 후 동결 건조기를 이용하여 완전 건조시켜 시호 추 출물을 제조하였으며 수율은 $26 \%$ 였다. 이를 냉동 $\left(-80{ }^{\circ} \mathrm{C}\right)$ 보관 하면서 실험 직전에 증류수에 희석하여 사용하였다. 육계 10 배 수의 $50 \%$ 에탄올을 가하여 상온 추출하였다. 이후 $50 \%$ 에탄올 추출물을 Whatman (No. 1, GE healthcare, Arlington Heights, $\mathrm{IL}, \mathrm{USA})$ filter paper로 여과하고, 이를 감압 농축하였으며, 실 험시까지 냉동보관하였다.

\section{TNBS에 의한 대장염 유발 동물실험}

실험은 아무런 처치를 하지 않은 정상군, $\mathrm{TNBS}$ 를 $1.6 \mathrm{mg} / 80$ $\mu \mathrm{L}$ 로 처치한 대조군, sulfasalazine $30 \mathrm{mg} / \mathrm{kg}$ 을 처리한 $30 \mathrm{sulfa}$ 투여군(30Sulfa), sulfasalazine $60 \mathrm{mg} / \mathrm{kg}$ 을 처리한 60sulfa 투여 군(60Sulfa), 그리고 Sulfasalazine $30 \mathrm{mg} / \mathrm{kg}$ 와 육계(Cinnamomi cortex) 와 시호(Bupleuri radix) 복합물 $30 \mathrm{mg} / \mathrm{kg}$ (SCB30)을 처 리한 $\mathrm{SCB} 30$ 투여군, 총 5그룹으로 분류하였으며, 각 군에 12 마리씩 배정하였다. Sulfasalazine과 육계 시호 복합물은 표기한 
용량에 따라 1 일 1 회 총 7 일간 경구 투여하였다. 마우스에 대 장염을 유발하기 위해 24시간 절식시킨 뒤, isoflurane으로 가볍 게 마취시킨 후 존대를 사용하여 saline $(0.9 \% \mathrm{NaCl}, \mathrm{pH} 7.4)$ 에 희석한 $1.6 \mathrm{mg} / 80 \mu \mathrm{L}$ 의 $\mathrm{TNBS}$ 를 항문으로부터 $4 \mathrm{~cm}$ 깊이로 주입하였다. 주입 후 30 초간 꼬리를 위로 세워서 정치시켜 대 장염을 유발시켰다. 모든 마우스들은 매일 몸무게를 측정하고 혈변, 점액변의 유무, 행동의 변화를 살펴보았으며 실험 8 일 째, 절식을 24시간 한 후, isoflurane으로 흡입마취하여, 심장에서 혈 액을 채취하였고 즉시 원심분리기를 이용해 혈청을 분리하였다. 그 후에, 대장과 비장을 적출한 뒤 무게를 측정한 후, 분석 전 까지 $-80{ }^{\circ} \mathrm{C}$ 로 급속 냉동하여 보관하였다. 실험동물의 체중은 전자체중계로 1 회/1일으로 동일 시간 동일 조건에서 측정하였 고, 실험종료일 체중에서 실험 개시 전 체중을 빼서 체중증가 량\{body weight gain $(\mathrm{g})\}$ 을 산출하였다.

\section{궤양성 대장염 평가}

정상군, 대조군, sulfasalazine 투여군, $\mathrm{SCB}$ 복합물 투여군을 8 일 째에 희생하여 맹장에서부터 대장의 말단까지 분리하였다. 분리 한 대장은 광학 디지털 카메라(DSC-HX50V, Sony, Tokyo, Japan)를 이용하여 촬영한 뒤 무게와 길이를 측정하였다. 전신 성 염증반응에서 나타나는 비장비대에 대한 약효를 평가하기 위 하여 비장 또한 적출하여 무게를 측정하였다. 비장의 무게는 마 우스의 체중으로 나누어 계산하였다.

\section{혈청의 산화적 스트레스 바이오마커 측정}

실험동물은 희생시키기 전 24시간 동안 절식시킨 후 심장에서 채혈을 하였다. 채혈한 혈액을 $4,000 \mathrm{rpm}$ 로 10 분간 원심 분리 하여 혈청을 얻었고 혈청은 $-80{ }^{\circ} \mathrm{C}$ 에 보관한 후 분석에 사용하 였다. 혈청 내의 Reactive oxygen species (ROS)를 측정하기 위하여 $25 \mathrm{mM} \mathrm{DCFH-DA}$ 를 혼합한 후, 형광 광도계를 이용하 여 0 분부터 매 5 분씩 emission wavelength of $530 \mathrm{~nm}$ 와 excitation wavelength of $485 \mathrm{~nm}$ 를 이용하여 30 분간 측정한 산출 값을 계산하였다. 또한 $\mathrm{ONOO}^{-}$를 측정하기 위하여, Kooy 등(1994)의 방법을 시행하여 측정하였다. 각 샘플을 $\mathrm{pH} \mathrm{7.4의}$ rhodamine buffer와 $5 \mathrm{mM}$ DHR 123 과 섞은 후 5 분간 $37^{\circ} \mathrm{C}$ 에 서 흔들어 준 후 5 분씩 30 분간 emission 파장 $535 \mathrm{~nm}$ 와 excitation 파장 $480 \mathrm{~nm}$ 를 이용하여 30 분간 측정한 산출 값을 계산하였다.

\section{Western Blot Analysis}

대장의 세포질단백질을 얻기 위해 $100 \mathrm{mM}$ Tris- $\mathrm{HCl}(\mathrm{pH} 7.4)$,

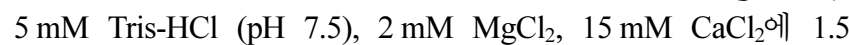
$\mathrm{M}$ sucrose, $0.1 \mathrm{M}$ DTT protease inhibitor cocktail을 첨가한 buffer $\mathrm{A}$ 를 넣고 tissue grinder로 분쇄한 후 10\% NP-40 용액 을 첨가하였다. 아이스 위에서 30 분간 정치시킨 후 $12,000 \mathrm{rpm}$ 으로 2 분간 원심분리 하여 세포질단백질을 포함하고 있는 상층 액을 분리하였다. 핵단백질을 얻기 위해 $10 \% \mathrm{NP}-40$ 가 더해진 buffer $\mathrm{A}$ 에 두 번 헹구고 $150 \mathrm{~mL}$ 의 buffer C $(50 \mathrm{mM}$ HEPES, $50 \mathrm{mM} \mathrm{KCl}, 0.3 \mathrm{mM} \mathrm{NaCl}, 0.1 \mathrm{mM}$ EDTA, $1 \mathrm{mM}$ DTT, 0.1 $\mathrm{mM} \mathrm{PMSF}$ and $10 \%$ glycerol)를 첨가해 재부유 시킨 뒤 10 분 마다 vortex를 3 번 하였다. $4^{\circ} \mathrm{C}$ 에서 $12,000 \mathrm{rpm}$ 으로 10 분간 원 심분리한 후 핵단백질을 포함하고 있는 상층액을 얻어 $-80{ }^{\circ} \mathrm{C}$ 에서 각각 냉동 보관하였다. 간 조직의 세포질단백질의 TNF- $\alpha$,
IL-6, IL-1 $\beta$, MCP-1, Bax, Cytochrome C, Caspase3, $\beta$-actin 의 발현을 측정하기 위해 $9 \mathrm{mg}$ 의 단백질을 $8-15 \% \mathrm{SDS}-$ polyacrylamide gel을 이용하여 전기영동 후, acrylamide gel을 nitrocellulose membrane으로 이동시켰다. 준비된 membrane에 각각의 1 차 antibody를 처리하여 $4{ }^{\circ} \mathrm{C}$ 에서 overnight 시킨 다음 PBST로 6 분마다 8회 세척하고, 각각 처리된 1차 항체에 사용 되는 2차 항체(PBST로 1:3000로 희석해서 사용)를 사용하여 상 온에서 1시간 반응시킨 후, PBST로 6분마다 5회 세척하였다. 그리고 enhanced chemiluminescence (ECL, GE Healthcare, Arlington Heights, IL, USA) 용액을 부어준 뒤, Sensi-Q2000 Chemidoc (Lugen Sci Co., Ltd., Seoul, Korea)에 감광시켜 단 백질 발현을 확인한 후, 해당 band를 ATTO Densitograph Software (ATTO Corporation, Tokyo, Japan)프로그램을 사용하 여 정량하였다.

\section{통계처리}

모든 수치는 평균 \pm 표준오차(Mean $\pm \mathrm{SEM}$ 로 표시하였으며, SPSS (22.0 for Windows program)를 사용하여 one-way analysis of variance (ANOVA)로 유의수준 $p$-value $<0.05$ 에서 검정하였다.

\section{결과 및 고찰}

\section{마우스 대장염 모델에 $\mathrm{SCB}$ 투여에 의한 체중변화}

$\mathrm{TNBS}$ 로 유발된 마우스 대장염 모델에서 $\mathrm{SCB}$ 를 실험 시작일 부터 종료일까지 매일 투여하여 체중의 변화를 측정한 결과, TNBS로 염증을 유발한 대조군은 정상군에 비하여 체중의 변화 가 유의성 있게 감소하였는데, 이는 $\mathrm{TNBS}$ 로 유발된 염증에 의 한 것으로 사료되는 바이다. 하지만, $\mathrm{SCB}$ 를 투여한 군에서는 유의적인 체중의 변화는 보이지 않았다(Table 1).

\section{육안적으로 보이는 손상에 대한 $\mathrm{SCB}$ 의 효과}

대장의 염증 소견들을 관찰하기 위하여 $\mathrm{TNBS}$ 를 항문으로 주 입하여 대장염을 유발 시킨 뒤, 실험 종료일 24시간 절식 후, isoflurane으로 흡입 마취하여 희생 후 대장을 적출하였다. 적출 한 대장의 외형을 살펴보았을 때 대조군의 경우 정상군에 비하

Table 1 Effects of Sulfasalazine $(30 \mathrm{mg} / \mathrm{kg})+$ Cinnamomi cortex and Bupleuri radix mixture $(30 \mathrm{mg} / \mathrm{kg}$ ) (SCB) on body weight of TNBSinduced colitis mice

\begin{tabular}{cccc}
\hline \hline \multirow{2}{*}{ Group } & \multicolumn{3}{c}{ Body weight } \\
\cline { 2 - 4 } & Initial $(\mathrm{g})$ & Final $(\mathrm{g})$ & Gain $(\mathrm{g})$ \\
\hline Normal & $20.89 \pm 0.49$ & $23.66 \pm 0.62$ & $2.77 \pm 0.37$ \\
Vehicle & $20.62 \pm 0.51$ & $21.65 \pm 0.76$ & $1.07 \pm 0.31^{\text {\# }}$ \\
30Sulfa & $20.98 \pm 0.40$ & $22.61 \pm 0.47$ & $1.67 \pm 0.21$ \\
60Sulfa & $20.64 \pm 0.47$ & $22.05 \pm 0.38$ & $1.41 \pm 0.31$ \\
SCB & $21.06 \pm 0.62$ & $22.40 \pm 0.60$ & $1.29 \pm 0.45$
\end{tabular}

Normal: normal mice. Vehicle: TNBS-induced control mice. 30Sulfa: Sulfasalazine $(30 \mathrm{mg} / \mathrm{kg})$-treated mice. 60 Sulfa: Sulfasalazine $(60 \mathrm{mg} /$ $\mathrm{kg})$-treated mice. SCB30: Sulfasalazine $(30 \mathrm{mg} / \mathrm{kg})$ plus Cinnamomi cortex and Bupleuri radix mixture $(30 \mathrm{mg} / \mathrm{kg}$ ) (SCB)-treated mice. All data are expressed mean $\pm \mathrm{SEM}, n=12$ mice per group. Vehicle group significance was compared to normal group ( $\left.{ }^{\#} p<0.01\right)$ 
(A)

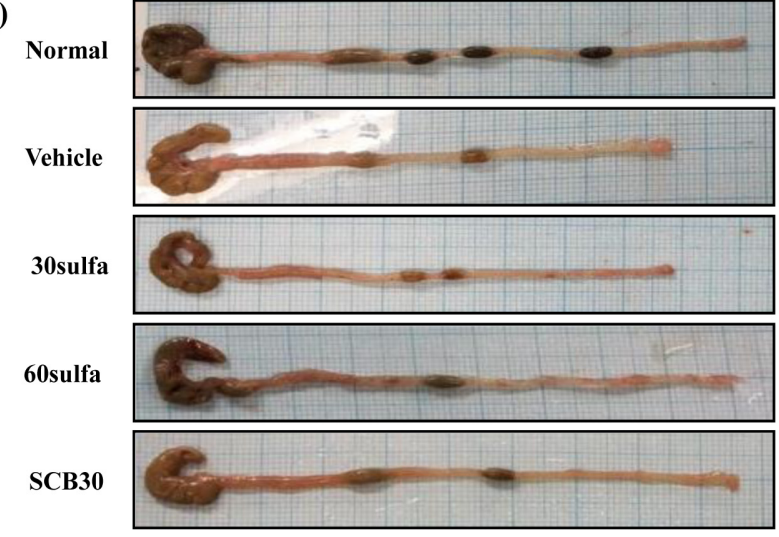

(B)

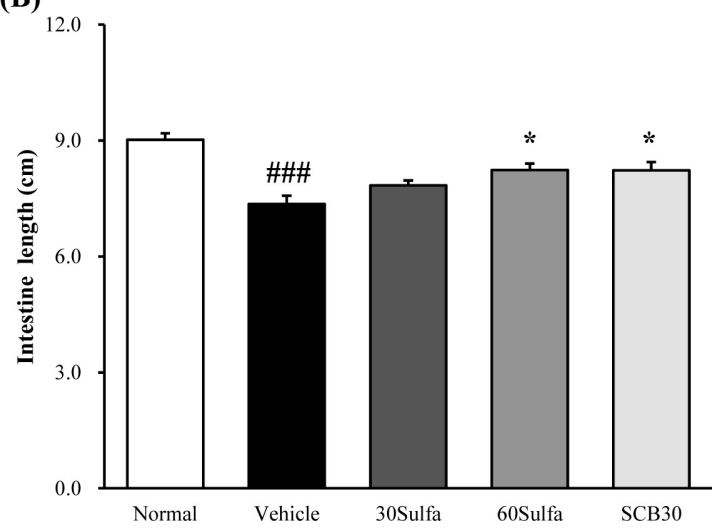

Fig. 1 Macroscopic changes of colons in TNBS and SCB treated mice. (A) Photograph of colon. Normal: normal mice. Vehicle: TNBS-induced control mice. 30Sulfa: Sulfasalazine $(30 \mathrm{mg} / \mathrm{kg})$-treated mice. 60Sulfa: Sulfasalazine $(60 \mathrm{mg} / \mathrm{kg})$-treated mice. SCB30: Sulfasalazine (30 mg/kg) plus Cinnamomi cortex and Bupleuri radix mixture $(30 \mathrm{mg} / \mathrm{kg}$ ) (SCB)-treated mice. (B) Graph for changes of intestine length. All data are expressed mean \pm SEM, $n=12$ mice per group. Vehicle group significance was compared to normal group $\left.{ }^{m} p<0.001\right)$. Sample group significance was compared to vehicle treated TNBS group $\left({ }^{*} p<0.05\right)$

여 벽의 두께가 얇아지고 충혈된 모습을 보였으며, 대장의 길 이 또한 짧아진 모습을 보였다(Fig. 1A). 맹장의 끝부터 대장 끝까지의 길이를 $\mathrm{SCB}$ 투여 8 일째에 측정한 결과, 정상군 $(9.02 \pm 0.17 \mathrm{~cm})$ 에 비해 대조군 $(7.36 \pm 0.21, p<0.001)$ 은 유의성 있 게 감소하여 이는 $(\mathrm{Kim}$ 등, $2008 ; \mathrm{Kim}$ 등, 2014)의 연구와 일 치하게 TNBS로 유발된 동물모델의 확립이 유효하게 이루어졌 음을 확인할 수 있었다.

투여군의 경우 $30 \mathrm{Sulfa}$ 투여군(7.84 \pm 0.18$)$ 은 대조군에 비해 증 가하였으나, 유의성이 없었고, $60 \mathrm{Sulfa}$ 투여군 $(8.24 \pm 0.17, p$ $<0.05)$ 은 대조군에 비해 유의성 있게 증가하였다. SCB30 투여 군 $(8.23 \pm 0.22, p<0.05)$ 은 대조군에 비해 유의성 있게 대장 길이 가 증가하는 것으로 나타나 $\mathrm{SCB}$ 복합물이 대장 길이 회복 효 과를 유의하게 했음을 확인할 수 있었다(Fig. 1B).

\section{비장의 변화에 대한 $\mathrm{SCB}$ 의 효과}

TNBS 유발 후 $\mathrm{SCB}$ 투여 8일째 되는 날 희생시킨 마우스의 비장을 적출하여 그 무게를 확인하여 염증 정도를 평가하였다. 비장은 $\mathrm{T}$ 세포, $\mathrm{B}$ 세포, 대식세포 등의 여러 가지 림프구가 밀 집되어있는 장기로서 생체 내 면역기능을 담당하는 면역기관이 다(Roitt 등, 1989). 비장의 무게를 측정하여 마우스의 체중으로 나누어 변화를 확인한 결과, 정상군 $(2.91 \pm 0.08 \mathrm{mg} / \mathrm{g})$ 에 비해 대 조군 $(3.38 \pm 0.05, p<0.001)$ 은 유의성있게 증가하였다.

약물 투여군의 경우 $30 \mathrm{Sulfa}$ 투여군(3.15 \pm 0.06$)$ 은 대조군에 비 하여 감소하였지만 유의성은 없었다. $60 \mathrm{Sulfa}$ 투여군 $(3.06 \pm 0.08$, $p<0.01)$ 은 대조군에 비하여 유의하게 감소하였고, SCB30 투여 군 $(3.01 \pm 0.04, p<0.01)$ 은 대조군에 비해 유의성 있게 비장 무게 가 감소하는 것으로 나타났다(Fig. 2). 이러한 유의한 결과는 (Jung 등, 2014) 의 연구와 일치하여 간경화, 간염, 췌장질환, 전 신 감염증, 등 여러가지 혈액 질환 등이 원인으로 비장비대가 나타나는데, 대장염으로 인한 비장비대에 $\mathrm{SCB}$ 가 유의적인 효 과를 보이는 것으로 사료된다.

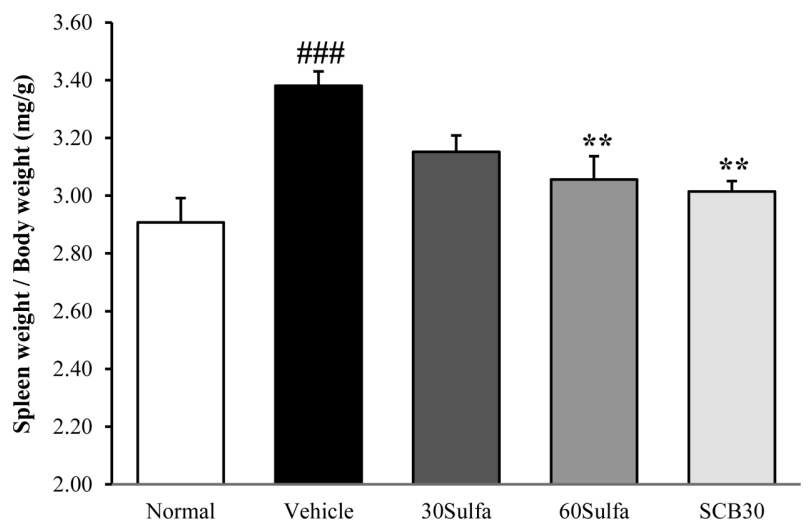

Fig. 2 Effect of SCB on spleen weight. The spleen weights were significantly increase in TNBS-treated mice in comparison to normal. 60Sulfa and SCB30-treated mice group showed a significant reduction of spleen weight. Normal: normal mice. Vehicle: TNBS-induced control mice. 30Sulfa: Sulfasalazine $(30 \mathrm{mg} / \mathrm{kg})$-treated mice. 60 Sulfa: Sulfasalazine $(60 \mathrm{mg} / \mathrm{kg})$-treated mice. SCB30: Sulfasalazine $(30 \mathrm{mg} / \mathrm{kg})$ plus Cinnamomi cortex and Bupleuri radix mixture $(30 \mathrm{mg} / \mathrm{kg})(\mathrm{SCB})$ treated mice. All data are expressed mean \pm SEM, $n=12$ mice per group. Vehicle group significance was compared to normal group ("\#\# $p<0.001$ ). Sample group significance was compared to vehicle treated TNBS group $(* * p<0.01)$

\section{산화적 스트레스 바이오마커 변화}

ROS는 다양한 세포 내 - 외 신호에 의하여 발생하며, 세포 내 신호전달에 영향을 주는 매개체이다(Shin 등, 2015). 과도한 $\mathrm{ROS}$ 의 생성은 DNA 및 미토콘드리아의 손상을 야기하여 apoptosis 유발 촉진 신호로 작용한다고 알려져 있다(Han 등, 2011). 본 연구자는 SCB30 복합물 처리에 의한 TNBS 대장염 모델의 apoptosis 유발이 ROS 생성과 연관성이 있는지의 여부 를 조사하였다. 산화적 스트레스 바이오마커 중 하나인 $\mathrm{ROS}$ 를 

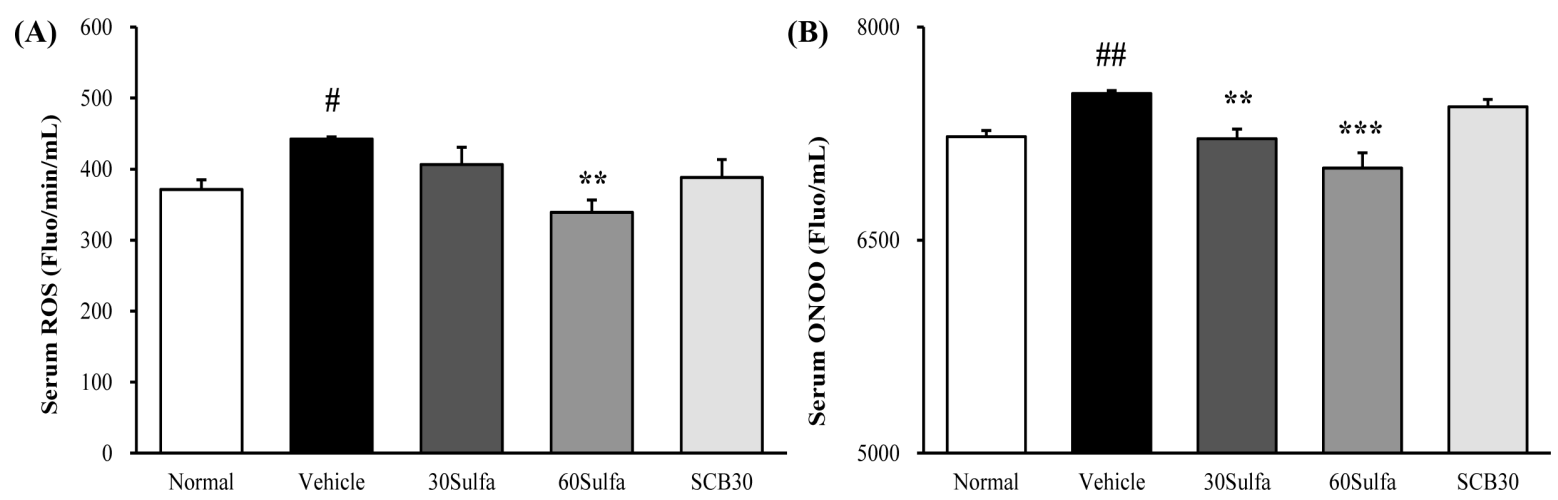

Fig. 3 Reactive Oxygen Species (ROS), Peroxynitrite $\left(\mathrm{ONOO}^{-}\right)$in Serum. (A) ROS in serum, (B) ONOO ${ }^{-}$in serum. Normal: normal mice. Vehicle: TNBS-induced control mice. 30Sulfa: Sulfasalazine $(30 \mathrm{mg} / \mathrm{kg})$-treated mice. 60Sulfa: Sulfasalazine $(60 \mathrm{mg} / \mathrm{kg})$-treated mice. SCB30: Sulfasalazine $(30 \mathrm{mg} / \mathrm{kg})$ plus Cinnamomi cortex and Bupleuri radix mixture $(30 \mathrm{mg} / \mathrm{kg})(\mathrm{SCB})$-treated mice. All data are expressed mean \pm SEM, $n=12 \mathrm{mice}$ per group. Vehicle group significance was compared to normal group $\left({ }^{\#} p<0.05,{ }^{\#} p<0.01\right)$. Sample group significance was compared to vehicle treated TNBS group $(* * p<0.01, * * * p<0.001)$

혈청에서 측정한 결과, 정상군 $(371.3 \pm 13.5$ fluorescence $/ \mathrm{min} / \mathrm{mL})$ 에 비하여 대조군 $(442.4 \pm 3.0, p<0.05)$ 은 증가하였고, $30 \mathrm{Sulfa}$ 투 여군(406.6 \pm 24.3$)$ 은 대조군에 비하여 감소하는 경향은 보였으나, 유의성은 없었고 $60 \mathrm{Sulfa}$ 투여군(338.9 $\pm 17.7, p<0.01)$ 은 대조군 에 비하여 유의성 있게 감소하였다. SCB30 투여군(388.3 \pm 25.2$)$ 은 대조군에 비하여 감소하는 경향은 보였지만, 유의성은 없었 다(Fig. 3A).

$\mathrm{ONOO}^{-}$의 측정 결과, 정상군 $(7228 \pm 43.8$ fluorescence $/ \mathrm{mL})$ 에 비하여 대조군 $(7531 \pm 21.9, p<0.01)$ 은 증가하였고, $30 \mathrm{Sulfa}$ 투여 군(7214 $\pm 67.6, p<0.01)$ 은 대조군에 비하여 유의성 있게 감소하 였다. 60Sulfa 투여군 $(7008 \pm 105.6, p<0.001)$ 또한 대조군에 비 하여 유의하게 감소하였지만, SCB30 투여군(7438 \pm 51.6$)$ 은 대조 군에 비하여 감소하는 경향은 보였지만, 유의한 결과를 보이지 는 않았다(Fig. 3B).

\section{대장 조직의 염증성 사이토카인 측정}

TNBS 유발 후 $\mathrm{SCB}$ 투여 8일째 되는 날 희생하여 마우스의 대장조직을 채취한 뒤 염증성 사이토카인인 TNF- $\alpha$, IL-6, IL$1 \beta$ 의 발현량을 확인하고, chemokine인 MCP-1의 발현량 또한 확인하였다. 염증성 사이토카인은 대장염에서 염증반응의 초기 에 수반되는데 TNF- $\alpha$ 의 생성증가는 상피세포의 사멸을 유도하 여 점막층을 파괴하고 염증반응이 지속적으로 일어날 수 있도 록 한다(Choi 등, 2009). TNF- $\alpha$ 에 의해 증가하는 MCP-1은 염 증 부위로 각종 면역 관련 세포들의 부착을 유도하는 주요 chemokine으로서, 대장염의 염증 병변을 악화시키는 것으로 알 려져 있다(Kim 등, 2008b).

$\mathrm{TNF}-\alpha$ 의 발현은 정상군 $(1.00 \pm 0.18)$ 에 비하여 대조군 $(1.96 \pm 0.17$, $p<0.01)$ 은 유의성 있게 증가하였고, 대조군에 비해 30Sulfa 투 여군(1.26 \pm 0.24$)$ 은 적게 발현하였으나 유의성은 없었고, $60 \mathrm{Sulfa}$ 투여군 $(1.04 \pm 0.23, p<0.05)$ 은 유의성 있게 적게 발현하였으며, $\mathrm{SCB} 30$ 투여군 $(1.12 \pm 0.11, p<0.05)$ 에서는 대조군에 비해 유의성 있게 감소하였다(Fig. $4 \mathrm{~A})$.

IL-6의 발현은 정상군 $(1.00 \pm 0.13)$ 에 비하여 대조군( $2.32 \pm 0.29$, $p<0.001)$ 은 유의성 있게 증가하였고, 대조군에 비해 30Sulfa 투 여군(1.86 \pm 0.25$)$ 과 $60 \mathrm{Sulfa}$ 투여군 $(1.76 \pm 0.05)$ 은 유의성은 없었
지만 감소하는 경향을 보였다. $\mathrm{SCB} 30$ 투여군 $(1.41 \pm 0.06, p<$ $0.05)$ 에서는 대조군에 비해 유의적으로 감소하였다(Fig. 4B).

$\mathrm{IL}-1 \beta$ 의 발현은 정상군 $(1.00 \pm 0.06)$ 에 비하여 대조군 $(1.40 \pm 0.06$, $p<0.01)$ 은 유의성 있게 증가하였고, 대조군에 비해 30Sulfa 투 여군(1.19 \pm 0.11$)$ 은 감소하는 경향은 보였지만 유의성은 없었다. 60 Sulfa 투여군 $(1.07 \pm 0.06, p<0.05)$ 은 대조군에 비하여 유의성 있게 적게 발현하였고, $\mathrm{SCB} 30$ 투여군 $(1.06 \pm 0.05, p<0.05)$ 도 대 조군에 비해 유의성 있게 적게 발현하였다(Fig. $4 \mathrm{C}$ ).

$\mathrm{TNF}-\alpha$ 에 의하여 증가하는 chemokine인 MCP-1의 발현은 정 상군 $(1.00 \pm 0.09)$ 에 비하여 대조군 $(1.51 \pm 0.14, p<0.05)$ 은 유의성 있게 증가하였고, 대조군에 비해 $30 \mathrm{Sulfa}$ 투여군 $(0.97 \pm 0.12, p<$ $0.05)$ 은 유의성 있게 적게 발현하였으며, $60 \mathrm{Sulfa}$ 투여군 $(0.95 \pm 0.07$, $p<0.01)$ 은 대조군에 비하여 유의성 있게 적게 발현하였다. $\mathrm{SCB} 30$ 투여군 $(0.94 \pm 0.12, p<0.01)$ 에서는 대조군에 비해 유의성 있게 감소하였다(Fig. 4D). 60Sulfa 투여군과 SCB30 투여군은 대조군에 비하여 유의성 있는 적은 발현을 보여 $\mathrm{SCB}$ 복합물은 $60 \mathrm{Sulfa}$ 투여군과 비교해 동등 또는 그 이상인 것으로 확인되 었다. 본 연구결과를 바탕으로 향후 $\mathrm{SCB}$ 의 항염효과 증대에 미 치는 영향 및 기전에 관한 규명을 통해서 sulfasalazine의 독성 및 부작용을 최소화 하면서 효과를 높일 수 있는 치료제의 개 발이 필요할 것으로 사료된다.

\section{대장조직의 세포자멸 관련 인자 측정}

염증은 일회성으로 발생하지만 장기간 발생한다면 암 유발에 있 어서 영향을 준다(Morson 등, 1985). 궤양성 대장염은 염증에 의한 발암을 유도하는데 있어서 대표적인 질환이고(Park 등, 2012), 궤양성 대장염이 없는 집단보다 대장암 발생율이 5.7배 정도 높은 것으로 확인되었다(Ekbom 등, 1990). 이에 TNBS로 유발된 대장염 동물모델에서 세포자멸과 관련된 인자의 단백질 발현량을 측정한 결과, 세포사멸촉진인자인 $\mathrm{Bax}$ 의 발현은 정상 군 $(1.00 \pm 0.08)$ 에 비하여 대조군 $(2.12 \pm 0.19, p<0.01)$ 은 유의성 있 게 증가하였고, 대조군에 비해 $30 \mathrm{Sulfa}$ 투여군(1.52 \pm 0.31$)$ 과 $60 \mathrm{Sulfa}$ 투여군 $(1.39 \pm 0.14)$ 은 유의성은 없지만 감소하는 경향을 보였다. $\mathrm{SCB} 30$ 투여군 $(1.22 \pm 0.13, p<0.05)$ 에서는 대조군에 비 해 유의성 있게 감소하였다(Fig. 5A). 
(A)

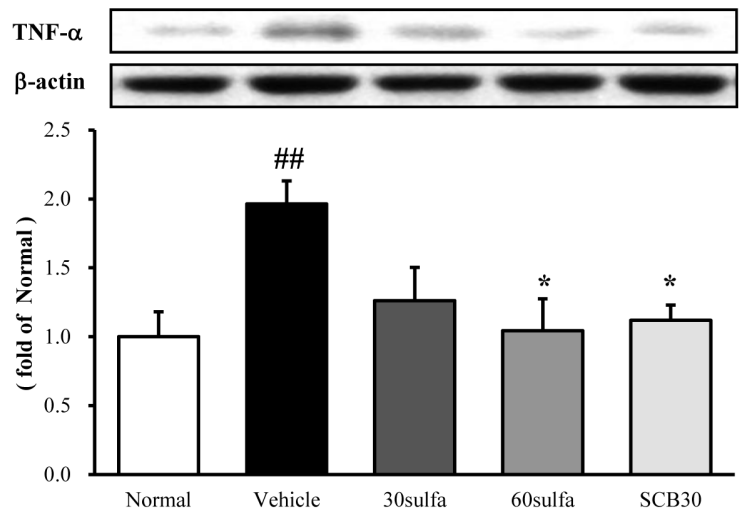

(C)
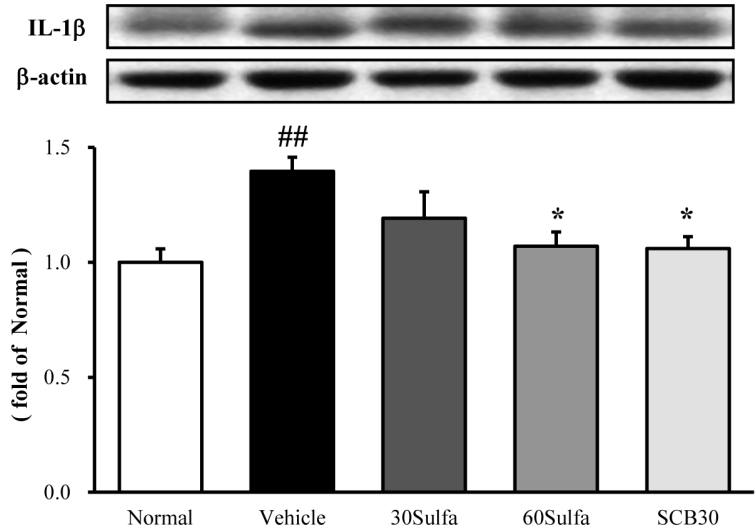

(B) IL-6

$\beta$-actin

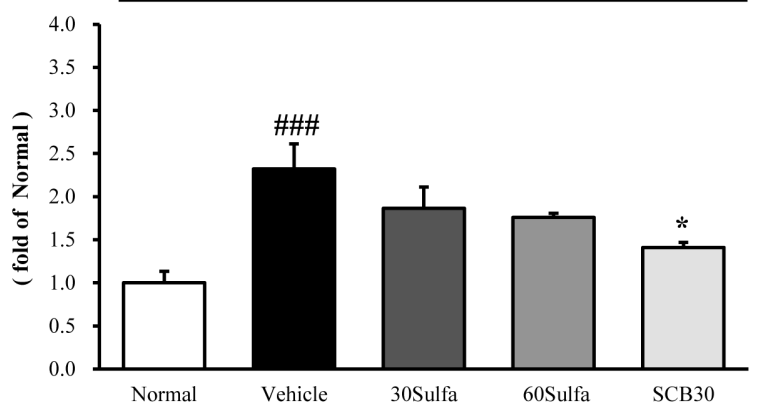

(D)
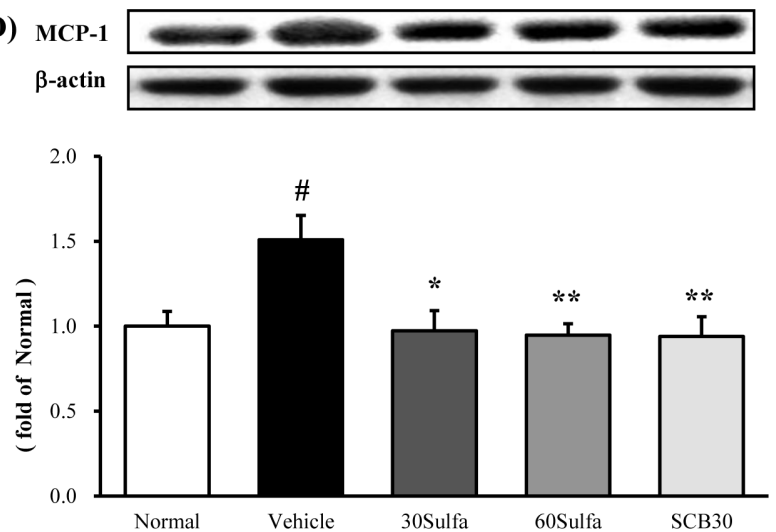

Fig. 4 Expression of Inflammation-related Proteins in Bowel. Inflammation-related proteins Tumor necrosis factor $\alpha$ (TNF $\alpha$ ): (A), Interlukin-6 (IL-6): (B), Interlukin-1 $\beta$ (IL-1 $\beta$ ): (C), monocyte chemoattractant peptide-1 (MCP-1): (D). Normal: normal mice. Vehicle: TNBS-induced control mice. 30Sulfa: Sulfasalazine $(30 \mathrm{mg} / \mathrm{kg})$-treated mice. $60 \mathrm{Sulfa}$ : Sulfasalazine $(60 \mathrm{mg} / \mathrm{kg})$-treated mice. SCB30: Sulfasalazine $(30 \mathrm{mg} / \mathrm{kg}) \mathrm{plus}$ Cinnamomi cortex and Bupleuri radix mixture $(30 \mathrm{mg} / \mathrm{kg})(\mathrm{SCB})$-treated mice. All data are expressed mean $\pm \mathrm{SEM}, n=12$ mice per group. Vehicle group significance was compared to normal group $\left({ }^{\#} p<0.05,{ }^{\#} p<0.01,{ }^{\#} p<0.001\right)$. Sample group significance was compared to vehicle treated TNBS group $\left({ }^{*} p<0.05,{ }^{* *} p<0.01\right)$

Cytochrome $\mathrm{C}$ 의 발현은 정상군 $(1.00 \pm 0.15)$ 에 비하여 대조군 (2.85 $\pm 0.33, p<0.001)$ 은 유의성 있게 증가하였고, 대조군에 비 해 30 Sulfa 투여군 $(1.73 \pm 0.33, p<0.05)$ 은 유의성 있게 적게 발 현하였고, $60 \mathrm{Sulfa}$ 투여군 $(1.70 \pm 0.21, p<0.05)$ 은 유의성 있게 적 게 발현하였다. $\mathrm{SCB} 30$ 투여군 $(1.36 \pm 0.22, p<0.01)$ 에서는 대조 군에 비해 유의성 있게 감소하였다(Fig. 5B).

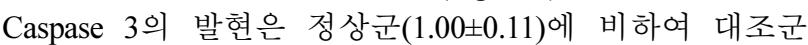
(2.10 $\pm 0.33, p<0.05)$ 은 유의성 있게 증가하였고, 대조군에 비해 30 Sulfa 투여군 $(1.45 \pm 0.34)$ 은 유의성은 없었지만 감소하는 경향 을 보였다. $60 \mathrm{Sulfa}$ 투여군 $(0.94 \pm 0.11, p<0.01)$ 은 유의성 있게 적게 발현하였고, $\mathrm{SCB} 30$ 투여군 $(1.02 \pm 0.14, p<0.05)$ 에서는 대 조군에 비해 유의성 있게 적게 발현하였다(Fig. 5C).

세포자멸(apoptosis)은 세포가 의도적으로 스스로 죽는 세포자 살을 의미하는데 이는 세포손상에 의한 세포괴사(necrosis)와는 다르다(Majno와 Joris 1995). 세포자멸사를 유발하는 신호전달 경로에서 세포 기질을 쪼개는 cysteine aspartyl-specific proteases (caspase)가 활성화되며, 이것이 세포자멸사의 생화학적, 형태학 적 변화를 유발한다(Krammer 1997; Cho와 Choi 2002). 세포 자멸사는 세포 표면에 위치한 죽음 수용체(death receptor)를 통
해 이루어지는 이루어지는 '세포 외부 경로'와, 미토콘드리아에 의해 이루어지는 '세포 내부 경로' 두 가지 신호 전달경로가 알 려져 있다(Schmitz 등, 2000). 세포 외부 경로의 세포에서는 활 성화된 caspase 8의 양이 충분하여 세포자멸사가 직접적으로 유 발되지만, 세포 내부 경로에서는 미토콘드리아가 세포자멸사의 증폭기로 사용된다(Chung 등, 2003). 미토콘드리아의 막이 자극 되면 cytochrome $\mathrm{C}$ 가 세포질로 방출되고, apoptotic protease activating factor 1과 결합체를 형성하여 caspase 9을 활성화한 다. Caspase 9은 caspase 3 등의 다른 caspase를 활성화시킴으 로써 세포자멸사를 유발한다(Choi 2001). 본 연구결과는 SCB 가 세포자멸에 관여하는 인자들의 단백질 발현량을 유의성 있 게 감소시킨다는 것으로 보아, $\mathrm{SCB}$ 가 항염효과 뿐 아닌 세포 자멸을 막을 수 있는 치료제로의 개발이 가능할 것으로 향후 더 많은 연구와 평가가 필요한 것으로 사료된다.

\section{초 록}

염증성 장 질환에 일반적으로 사용되는 설파살라진은 고용량 및 

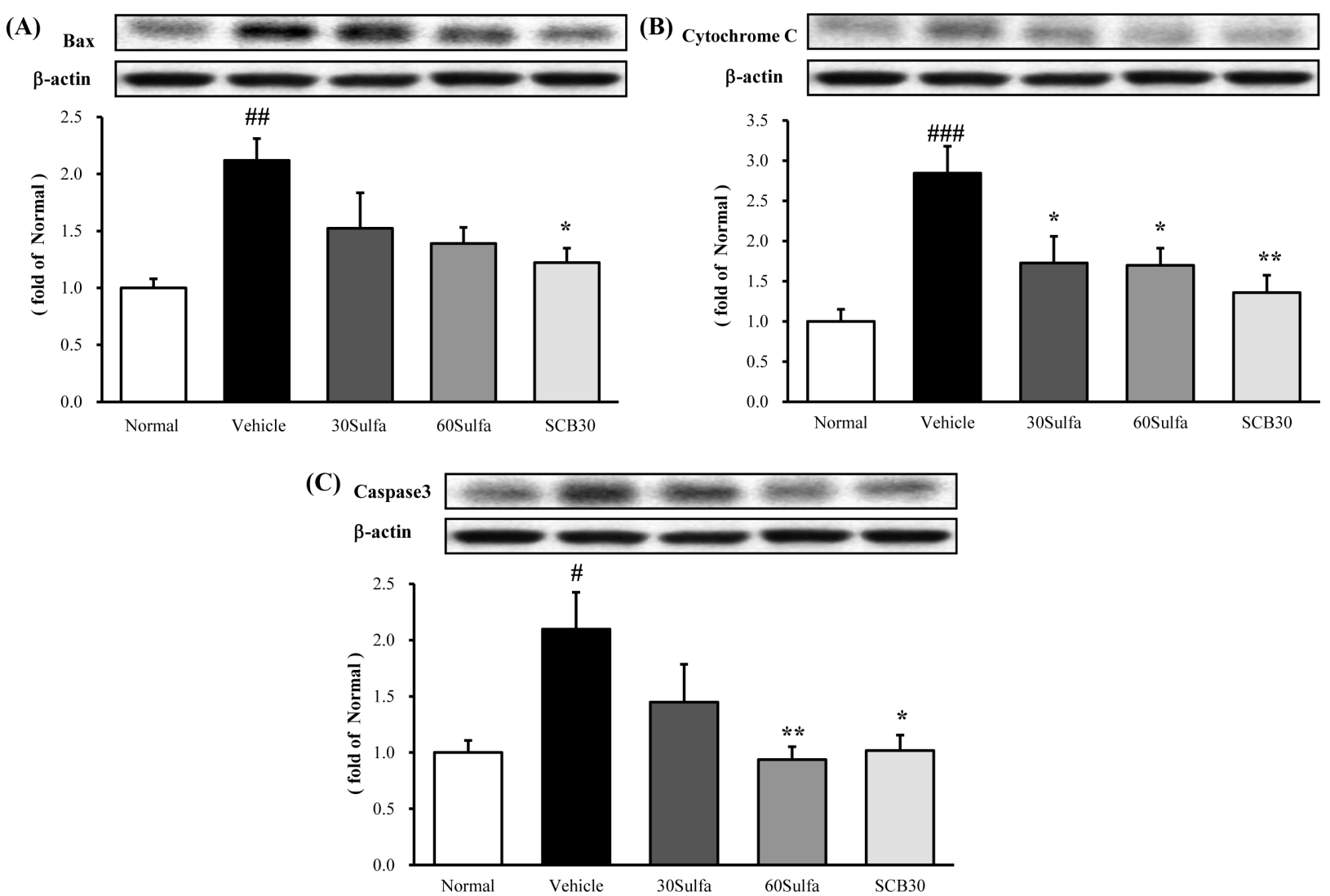

Fig. 5 Expression of apoptosis-related Proteins in Bowel. Bax: (A), Cytochrome C: (B), Cysteine aspartyl-specific proteases 3 (Caspase 3): (C). Normal: normal mice. Vehicle: TNBS-induced control mice. 30Sulfa: Sulfasalazine (30 mg/kg)-treated mice. $60 \mathrm{Sulfa}$ : Sulfasalazine $(60 \mathrm{mg} / \mathrm{kg})$-treated mice. SCB30: Sulfasalazine (30 mg/kg) plus Cinnamomi cortex and Bupleuri radix mixture $(30 \mathrm{mg} / \mathrm{kg})(\mathrm{SCB})$-treated mice. All data are expressed mean \pm SEM, $n=12$ mice per group. Vehicle group significance was compared to normal group $\left({ }^{\#} p<0.05,{ }^{\#} p<0.01,{ }^{\# \#} p<0.001\right)$. Sample group significance was compared to vehicle treated TNBS group $(* p<0.05, * * p<0.01)$

장기 섭취 후 다양한 부작용이 있다. 본 연구에서는 TNBS로 유발된 마우스 대장염 모델에서 설파살라진, 육계와 시호 복합 추출물의 항염증 및 세포 자멸 개선효과를 확인하고자 하였다. 실험은 정상군, TNBS 대조군, Sulfasalazine $(30 \mathrm{mg} / \mathrm{kg})$ 군, Sulfasalazine $(60 \mathrm{mg} / \mathrm{kg})$ 군, Sulfasalazine $(30 \mathrm{mg} / \mathrm{kg})+$ 육계 및 시호 혼합 $(30 \mathrm{mg} / \mathrm{kg})$ 군, 총 5 개의 군으로 나누었으며, 7 일간 경 구투여 하였다. 염증 및 세포 자멸 단백질은 western blot을 통 해 발현량을 확인하였다. SCB 투여는 염증 단백질 및 세포 자 멸과 관련된 단백질의 억제에 유의한 효과를 나타냈다. 이러한 결과로 보아 설파살라진, 육계와 시호 복합 추출물은 염증과 세 포 자멸의 억제를 통해 염증성 장 질환을 개선시킬 수 있으며, 염증성 장 질환의 치료 대안 가능 물질로 사료되는 바이다.

Keywords 궤양성대장염 - 설파살라진 - 세포자멸사 - 양한방융 복합약물 - 항염증 - Trinitrobenzene sulfonic acid

감사의 글 본 연구는 한국보건산업진흥원을 통한 양한방융합기반기술개발 사업의 지원을 받아 진행하였습니다(KHIDI, HI15C00255).

\section{References}

Cho JG, Kim JM (1994) Effect of Buplerum falcatum on the immune system. Korean J Vet Res 34: 769-779

Cho SG, Choi EJ (2002) Apoptotic Signaling Pathways: Caspases and StressActivated Protein Kinases. BMB Reports 35: 24-27

Cho SW, Kim YK (2009) Studies on Protective Effect of Bupleurum falcatum Extract (SHI-1909) against Experimental Inflammatory bowel Disease Model. J Korean KAIS 10: 613-619

Choi EJ (2001) Apoptotic signaling pathways. Exp Mol Med 33: 85S-95S

Choi SW, Kang H, Shim BS, Kim SH, Choi SH, Ahn KS (2009) Effect of Bupleuri Radix on Inflammatory Cytokine Secretion to HMC and Mouse Immmune Cells. Korean J Oriental Physiology \& Pathology 23: $150-157$

Han W, Hu WC, Lee YM (2011) Anti-cancer Activity of Human Colon Cancer(HT-29) Cell Line from Different Fraction of Zanthoxylum schnifolium Fruits. Kor J Pharmacogn 42: 282-287

Hyun MS, Hur JM (2011) Lactic Acid Fermentation of Dioscorea batatas and Its Anti-Inflammatory Effects on TNBS-induced Colits Model. J Appl Biol Chem 54: 51-55

Je HD (2012) Antinociceptive and Anti-inflammatory Properties of Cinnamomum cassia Derived-cinnamaldehyde in Rodents. Yakhak Hoeji 
56: 236-239

Kim DG, Yoo DY (2012) The Effects of Cinnamomum loureirii on Osteoblast in Murine Rat Calvarial Cells. J OOG 25: 061-070

Kim ES, Shin MK, Kim TR, Shin MH, Lee YS (2015) Effect of Ohmaehwan and Mume Fructus on DSS-Induced Inflammatory Bowel Disease in a Mice Model System. J Int Korean Med 36: 284-296

Kim KJ, Kim JT, Lee ES, Lee JS, Kim JA (2008b) 1-Furan-2-yl-3-Pyridine-2yl-Propenone Inhibits TNF- $\alpha$-induced Intestinal Inflammation via Suppression of MCP-1 and IL-8 expressions in HT-29 Human Colon Epithelial Cells. Yakhak Hoeji 52: 402-406

Kim SJ, Kim SH, Lim YI, Kim YG, Park KY (2014) Inhibitory Effects of Ginger and Beopje Ginger on DSS-induced Colitis in Mice. J Korean Soc Food Sci Nutr 43: 477-484

Kim SM, Jeong MW, Kim YS, Lee JY, Jeong JK, Kim SJ et al (2013) Inhibitory Effects of Sulfur-Fed Duck Extracts on DSS-induced Colitis in Mouse. J Korean Soc Food Sci Nutr 42: 1567-1575

Kim SY, Ryu BH, Park JW (2008a) Effects of Samiunkyungtang on inflammation and fecal enzymes in ulcerative colitis animal model. J Korean Oriental Med 29: 50-62

Kooy NW, Royall JA, Ischiropoulos H, Beckman JS (1994) Peroxynitritemediated oxidation of dihydrorhodamine 123 . Free Radic Biol Med 16 149-156

Krammer PH (1997) CD95 (APO-1/Fas)-mediated apoptosis: live and let die.
Adv Immunol 71: 163-210

Kye BH (2016) Nutritional Supports in Patients with Inflammatory Bowel Disease. J Clin Nutr 8: 11-18

Lee KH, Rhee KH (2010) Anti-Inflammatory Effects of Glycyrrhiza glabra Linne Extract in a Dextran Sulfate Sodium-Induced Colitis Mouse Model. Korean J Food \& Nutr 23: 435-439

Lee SY, Kim HS, Kim JO, Hwang JW, Hwang SY (2006) Effect of Ethanol Extracts of Cinnamon on the Proliferation and COX.2 Pathway in HT.29 Human Colon Cancer Cell Line. J Korean Soc Food Sci Nutr 35: 11151120

Majno G, Joris I (1995) Apoptosis, oncosis and necrosis: an overview of cell death. Am J Patho 146: 3-15

Myung NI (2014) The inhibitory effect of Orostachys japonicus on dextran sulfate sodium-induced colitis in mice. Kor J Herbology 29: 29-34

Park JH, Seo BI (2015) A philological study on poisoning and side effects of Cinnamomi Cortex. J A O M 15: 1-6

Park YC, Park YK, Lee SD (2012) The various mechanisms of Korean traditional medicines for anti-cancer. Kor J Herbology 27: 39-55

Shin SH, Shin YO, Lee JY, Lee AR, Kim MY, Park CH et al (2015) EthanolHeated Processed Scutellariae Radix Improve Inflammatory Response through an Inhibitory Effect against Oxidative Stress in Mice with the Lipopolysaccharide-induced Intestine Injury of Mice. Kor J Herbology 30: $81-88$ 